\title{
Estrogen receptor $\beta$ represses Akt signaling in breast cancer cells via downregulation of HER2/ HER3 and upregulation of PTEN: implications for tamoxifen sensitivity
}

Karolina Lindberg ${ }^{1}$, Luisa A Helguero², Yoko Omoto', Jan-Åke Gustafsson ${ }^{1,3}$ and Lars-Arne Haldosén ${ }^{1 *}$

\begin{abstract}
Introduction: The inhibition of estrogen receptor (ER) $\alpha$ action with the ER antagonist tamoxifen is an established treatment in the majority of breast cancers. De novo or acquired resistance to this therapy is common. Expression of ER $\beta$ in breast tumors has been implicated as an indicator of tamoxifen sensitivity. The mechanisms behind this observation remain largely uncharacterized. In the present study, we investigated whether ER $\beta$ can modulate pathways implicated in endocrine resistance development.
\end{abstract}

Methods: T47-D and MCF-7 ER $\alpha$-expressing breast cancer cells with tetracycline-regulated expression of ER $\beta$ were used as a model system. Expression levels and activity of known regulators of endocrine resistance were analyzed by performing quantitative polymerase chain reaction assays, Western blot analysis and immunostaining, and sensitivity to tamoxifen was investigated by using a cell proliferation kit.

Results: Expression of ER $\beta$ in ER $\alpha$-positive T47-D and MCF-7 human breast cancer cells resulted in a decrease in Akt signaling. The active form of an upstream regulator of Akt, proto-oncogene c-ErbB-2/receptor tyrosine kinase erbB-3 (HER2/HER3) receptor dimer, was also downregulated by ER $\beta$. Furthermore, ER $\beta$ increased expression of the important inhibitor of Akt, phosphatase and tensin homologue deleted on chromosome 10 (PTEN). Importantly, ER $\beta$ expression increased the sensitivity of these breast cancer cells to tamoxifen.

Conclusions: Our results suggest a link between expression of ER $\beta$ and endocrine sensitivity by increasing PTEN levels and decreasing HER2/HER3 signaling, thereby reducing Akt signaling with subsequent effects on proliferation, survival and tamoxifen sensitivity of breast cancer cells. This study supports initiatives to further investigate whether ER $\beta$ presence in breast cancer samples is an indicator for endocrine response. Current therapies in ERo-positive breast cancers aim to impair ERo activity with antagonists or by removal of endogenous estrogens with aromatase inhibitors. Data from this study could be taken as indicative for also using ER $\beta$ as a target in selected groups of breast cancer.

\section{Introduction}

Approximately two-thirds of breast cancers express estrogen receptors (ERs) and initially require estrogen to grow, and are therefore treated with ER antagonists, such as tamoxifen, or by depletion of endogenous estrogens with aromatase inhibitors [1,2]. Two ERs, ER $\alpha$ and

\footnotetext{
* Correspondence: lars-arne.haldosen@ki.se

'Department of Biosciences and Nutrition, Novum, Karolinska Institutet, Blickagången 6, S-141 83 Huddinge, Sweden Full list of author information is available at the end of the article
}

ER $\beta$, have been identified [3]. ER $\alpha$ plays an important role in the proliferation and progression of breast cancer, whereas a distinct function of ER $\beta$ in breast cancer initiation and development has not yet been clearly established. In in vitro settings, ER $\beta$ inhibits proliferation, migration and invasion of breast cancers cells [4-9] as well as the growth of breast tumor xenografts [10].

$\mathrm{ER} \alpha$ is the marker of choice to decide endocrine treatment of breast cancer. However, in the case of tamoxifen treatment, despite the initial response to the
C Biomed Central 
therapy, one-third of patients will acquire resistance even though their ER $\alpha$ status may remain unchanged [11]. ER $\beta$ has also been considered a marker of endocrine response. Lower expression of ER $\beta$ is found in tamoxifen-resistant tumors, and high levels of ER $\beta$ are sometimes associated with a better clinical outcome in ER $\alpha$-expressing breast tumors [12]. However, some studies have indicated that in high-grade, ER $\alpha$-negative, node-positive breast tumors, ER $\beta$ presence appears to be a marker related to a more aggressive breast cancer [13].

Breast tumors overexpressing receptor tyrosine kinases (RTKs) are less likely to benefit from tamoxifen treatment [14-17]. Receptor tyrosine protein kinase erbB-3 (HER3) and proto-oncogene $c$-ErbB-2 (HER2) are members of the epidermal growth factor receptor (EGFR) family. HER3 lacks intrinsic kinase activity and relies on heterodimerization with other members of the EGFR family for transduction of signals. There is growing awareness of the importance of HER2/HER3 heterodimer formation in breast cancer progression, where coexpression of HER2 and HER3 has been shown to be a poor prognostic indicator associated with resistance to endocrine therapy and to HER tyrosine kinase inhibitors [18-22]. The majority of HER2-positive tumors are strongly positive for HER3 [18], which is also seen in mouse models of breast cancers, where high expression of HER2 is commonly associated with activated and overexpressed HER3 [23]. Furthermore, inhibition of HER2 correlates with reduction in HER3 phosphorylation [24] and, correspondingly, inhibition of HER3 reduces phosphorylation of HER2 and abrogates HER2mediated tamoxifen resistance [25].

Phosphatidylinositol 3-kinase (PI3K) promotes generation of phosphatidylinositol $(3,4,5)$-triphosphate (PIP3), which leads to phosphorylation and activation of the serine/threonine kinase Akt. The PI3K/Akt pathway plays important roles in regulating cell proliferation, growth, apoptosis and motility. Increased activity due to genetic changes is frequently seen in breast cancer, resulting in tumor progression, metastases and resistance to endocrine treatment [26-29]. Mutation of the PIK3CA gene, which encodes the p110 $\alpha$ catalytic subunit of PI3K, leads to activation of Akt and is found in $18 \%$ to $40 \%$ of human breast cancers [30-32]. Stimulation of RTKs also activates Akt [33-35], and overexpression of HER2 is linked to elevated Akt activities [36-38]. In ER $\alpha$-positive breast cancers treated with tamoxifen, detection of activated Akt at diagnosis has been shown to correlate to decreased overall survival [39].

Constitutive active Akt is also associated with loss of phosphatase and tensin homologue deleted on chromosome 10 (PTEN) expression [40]. PTEN is a tumor suppressor whose expression is often lost in breast cancers and associated with poor disease outcome [41-44]. PTEN antagonizes PI3K activity by dephosphorylating PIP3, resulting in lower levels of active Akt [45].

The goal of this study was to investigate whether ER $\beta 1$ (referred to hereinafter as ER $\beta$ ) has any effect on the RTK/PI3K/Akt signaling pathway and thereby represents a regulator of tamoxifen sensitivity. We show that in ER $\alpha$-positive breast cancer cells, expression of ER $\beta$ reduced Akt activation through downregulation of HER2/HER3 signaling and upregulation of PTEN and, importantly, increased sensitivity to tamoxifen. ER $\beta$ has sometimes been suggested as a predictor of endocrine response; however, the mechanisms underlying this response are still unknown. Here we suggest a link between expression of ER $\beta$ and endocrine sensitivity.

\section{Materials and methods Cell cultures}

T47-D cells with tetracycline-regulated expression of ER $\beta 485$ (T47-DER $\beta$ ) [4] were routinely grown not expressing ER $\beta$ (-ER $\beta$ ) in RPMI 1640 medium (Invitrogen, Paisley, United Kingdom) supplemented with 5\% heat-inactivated fetal bovine serum (FBS) (Invitrogen), $1 \%$ penicillin-streptomycin (Invitrogen) and $10 \mathrm{ng} / \mathrm{mL}$ doxycycline (Sigma, Stockholm, Sweden). For experiments, cells were grown for 24 to 168 hours prior to analysis in phenol red-free RPMI 1640 medium supplemented with $2 \%$ heat-inactivated FBS, $1 \%$ penicillinstreptomycin, $10 \mathrm{ng} / \mathrm{mL}-\mathrm{ER} \beta$ or $0.01 \mathrm{ng} / \mathrm{mL}$ doxycycline $+E R \beta$ in the presence of vehicle alone, ethanol and/or dimethyl sulfoxide (Sigma), or in $10 \mathrm{nM}$ 2,3-bis (4-hydroxy-phenyl)-propionitrile (DPN) (Tocris, Bristol, United Kingdom), $10 \mathrm{nM}$ 4,4',4"-(4-propyl-[1 H]-pyrazole-1,3,5-triyl)trisphenol (PPT) (Tocris), $10 \mathrm{nM} 17 \beta$ estradiol (E2) (Sigma), 10 nM 7-bromo-2-(4-hydroxyphenyl)-1,3-benzoxazol-5-ol (WAY) (Tocris), $100 \mathrm{nM}$ ICI 182, 789 (ICI) (Tocris) or 100 to $1,000 \mathrm{nM} \mathrm{4-}$ hydroxy-tamoxifen (4-OH-T) (Sigma). MCF-7 breast cancer cells with tetracycline-regulated expression of ER $\beta 485$ were treated in a similar manner. T47-DPBI cells (Mock) were used as controls.

\section{Quantitative real-time polymerase chain reaction assays}

Cells were grown in six-well tissue culture plates for 24 to 96 hours and lysed in TRIzol reagent (Invitrogen), then RNA was extracted and cDNA was synthesized as described previously [46]. Quantitative real-time polymerase reaction assays (qRT-PCR) were performed with SYBR Green PCR Master Mix in an ABI PRISM 7500 (Applied Biosystems, Foster City, USA). The following primers were used: $18 \mathrm{~S}$ forward 5'-CCTGCGGCTTAATTTGACTCA-3', reverse 5'-AGCTATCAATCTGTCAATCCTGTCC-3'; $E R \beta$ forward 5'-ACTTGCTGAACGCCGTGACC-3', reverse 5'-CAGATGTTCCA- 
TGCCCTTGTT-3'; HER2 forward 5'-AAAGGCCCAAGACTCTCTCC-3', reverse 5'-CAAGTACTCGGGGTTCTCCA-3'; HER3 forward 5'-GTCATGAGGGCGAACGAC-3', reverse 5'-AGAGTCCCAGGACACACTGC-3'; and PTEN forward 5'-GGGGAAGTAAGGACCAGAGAC-3', reverse 5'-TCCAGATGATTCTTTAACAGGTAGC-3'. Quantification was carried out following the supplier's protocols using the standard curve method.

\section{Whole-cell extracts}

Cells grown on plates were washed with ice-cold phosphate-buffered saline (PBS), transferred to Eppendorf tubes and pelleted by centrifugation. Cell pellets were freeze-thawed and resuspended with PBS-TDS buffer (PBS with $1 \%$ Triton X-100, 0.5\% sodium deoxycholate, $0.1 \%$ sodium dodecyl sulfate (SDS), $1 \mathrm{mM}$ ethylenediaminetetraacetic acid and phosphatase inhibitors (Sigma)), incubated for 30 minutes on ice and centrifuged at $11,000 \mathrm{rpm}$ for 10 minutes at $4^{\circ} \mathrm{C}$. Supernatants were collected for further analysis. Protein quantification was carried out using a bicinchoninic acid protein assay kit (Pierce Biotechnology, Rockford, USA).

\section{Western blot analysis}

Forty micrograms of total cellular protein were separated using 7.5\% SDS-polyacrylamide gel electrophoresis and electrotransferred onto a nitrocellulose membrane (Hybond-C; AmershamBuckinghamshire, United Kingdom). After blocking in 5\% milk protein (wt/vol) in PBS, $0.1 \%$ Tween 20 ( $\mathrm{vol} / \mathrm{vol})$ membranes were sequentially incubated with primary and secondary antibodies. The following antibodies were used: anti-ER $\beta$ (14021; Abcam, Cambridge, United Kingdom), GTX110607 (GeneTex, Irvine, USA), anti-phospho-HER3 tyr1289 (21D3; Cell Signaling Technology, Danvers, USA), anti-phospho-Akt pathway sampler kit (9916; Cell Signaling Technology), anti-phospho-HER2 antibody sampler kit (9923; Cell Signaling Technology), anti-PTEN (26H9; Cell Signaling Technology); anti- $\alpha$-tubulin (11H10; Cell Signaling Technology), anti-EGFR (E12020; Transduction Laboratories, Franklin Lakes, USA), anti-HER3 (sc-285; Santa Cruz Biotechnology, Santa Cruz, CA, USA) and anti- $\beta$-actin (Sigma). The secondary antibodies were horseradish peroxidase-conjugated (Sigma). Visualization was carried out using the ECL Plus kit (Amersham) or the SuperSignal West Pico kit (Pierce Biotechnology). At least three independent experiments were carried out.

\section{Immunofluorescence}

Cells were cultured on sterilized glass coverslips in highor low-doxycycline conditions for 4 days as described above. The cells were fixed by ice-cold methanol and icecold acetone for 10 minutes and 1 minute, respectively.
Blocking of nonspecific binding was done with BlockAce (Dainippon Pharmaceutical, Osaka, Japan) for $1 \mathrm{~h}$ at room temperature. The samples were then incubated overnight at $4{ }^{\circ} \mathrm{C}$ with the following antibodies at the indicated dilutions in 10\% BlockAce in PBS: anti-HER2, 1:150 (29D8; Cell Signaling Technology), and anti-PTEN, 1:100 (26H9; Cell Signaling Technology). After washes with PBS, samples were incubated with corresponding Alexa Fluor 568conjugated secondary antibody 1:500 (Invitrogen) and Hoechst $333425 \mu \mathrm{g} / \mathrm{mL}$ (Molecular Probes, Eugen, USA) in PBS for 1 hour at room temperature. Samples were mounted with VECTASHIELD (Vector Laboratories, Burlingame, USA) after washes with PBS. Negative controls were incubated without primary antibody. To compare staining intensity between different samples, pictures were obtained with fixed exposure time. Staining was repeated three times to confirm consistent results.

\section{Fluorescence imaging}

Pictures of fluorescence staining were captured with a Zeiss Axioplan 2 microscope using Zeiss Plan-Apochromat $63 \times / 1.40$ oil lens (Carl Zeiss, Oberkochen, Germany). Images were acquired with a Zeiss AxioCam $\mathrm{MRm}$ camera under the same settings. Captured images were processed using the AxioVision Rel 4.6 program and edited using Adobe PhotoShop C54 software (Adobe, San Jose, USA), and the same adjustments were applied to all images.

\section{Cell proliferation}

T47-DER $\beta$ and MCF-7ER $\beta$ cells were cultured for 3 days in high (-ER $\beta)$ or low (+ER $\beta)$ doxycycline concentrations in the absence or presence of vehicle, E2 or WAY. On the third day, cells were replated on 96-well plates and allowed to adhere for 24 hours. Thereafter increasing concentrations of 4-OH-T were added. Growth medium was changed every other day. Cell viability was measured after 0,5 and 7 days of incubation with 4-OH-T using a colorimetric assay (WST-1; Roche, Basel, Switzerland) following the manufacturer's suggestions. Measurement of absorbance was done using a SpectraMax 250 microplate reader (Molecular Devices, Sunnyvale, USA) against a background control as blank.

\section{Statistical analysis}

Differences between more than two groups were compared by one-way analysis of variance and Tukey's multiple posttest using GraphPad software (GraphPad, San Diego, USA).

\section{Results and discussion}

\section{AKT signaling is repressed by ER $\beta$}

To assess the effect of ER $\beta$ on Akt signaling in human breast cancer cells, ER $\alpha$-expressing T47-D and MCF-7 
cells with inducible expression of ER $\beta$ (T47-DER $\beta$ and MCF-7ER $\beta$, respectively) were grown at inducing conditions for different times, and active Akt as well as the activity of a downstream target were investigated by immunoblot analysis. Both cell lines used in the present study have PIK3CA mutations, H1047R (catalytic domain) in T47-D and E545K (helical domain) in MCF7 cells [47], resulting in active Akt, higher in T47-D, at low stimulatory conditions. In both cell lines, expression of ER $\beta$ clearly downregulated phosphorylated Akt (pAkt) (Additional file 1). To further analyze the ER $\beta$ effect, pAkt levels were assessed throughout 1 to 7 days (Figure 1A). In T47-DER $\beta$ cells, levels of pAkt were clearly downregulated by ER $\beta$ after 4 and 7 days of ER $\beta$ induction (Figure 1A). No additional effect was seen upon the addition of the selective ER $\beta$ agonist DPN. Levels of total Akt protein did not change, indicating that reduced pAkt levels were due to less phosphorylation. Downregulation of pAkt was also observed upon ER $\beta$ expression in MCF-7ER $\beta$ cells (Figure 1B), showing that this is not a unique ER $\beta$ effect in one selected T47$\mathrm{D}$ cell clone. Moreover, pAkt levels in the mock cell line T47-DPBI were not affected by different doxycycline concentrations (Figure 1C), indicating that levels of pAkt are influenced not by doxycycline, but by induction of ER $\beta$ expression. One downstream target of Akt is GSK3 $\beta$. Following ER $\beta$ expression, pAkt downregulation correlated with reduced levels of phosphorylated GSK3ß (Figure 1A).

Since addition of the ER $\beta$ ligand DPN exerted no stable, repeatable additional effect to that already observed following ER $\beta$ expression (Figure 1 and 1 data not shown), we investigated whether ER antagonists would prevent ER $\beta$-induced decrease of Akt phosphorylation. For this purpose, ICI 182, 780 (ICI), a selective ER downregulator, and the selective estrogen modulator 4-OH-T were used. As expected, ICI induced complete downregulation of ER $\alpha$ (Figure 1D). ER $\beta$ protein levels were partially downregulated by ICI, whereas 4-OH-T had no significant effect on either ER $\alpha$ or ER $\beta$ protein levels (Figure 1E). Furthermore, ER $\alpha$ protein levels were reduced in cells expressing ER $\beta$ (Figures $1 \mathrm{D}$ and $1 \mathrm{E}$ ). This latter finding was consistently observed in all inducible systems that we tested. Treatment with ICI or 4-OH-T did not inhibit the ER $\beta$-induced decrease of pAkt levels. However, in ICI- or 4-OH-T-treated cells, the ER $\beta$-induced decrease of pAkt levels was less than that in cells not exposed to ICI or 4-OH-T, suggesting a weak antagonistic action of ICI and 4-OH-T. In summary, in two different ER $\alpha$-expressing human breast cancer cell lines, ER $\beta$ expression clearly reduced activation of the Akt signaling pathway.

\section{ER $\beta$ regulation of HER2 and HER3 expression}

Members of the EGFR family are potent activators of the PI3K/Akt pathway, contributing to endocrine resistance in breast tumors. Therefore, we investigated the effect of ER $\beta$ expression on EGFR, HER2 and HER3 protein levels in T47-D and MCF-7 cells. Upon ER $\beta$ expression, levels of EGFR were unchanged in T47DER $\beta$ cells (Figure 2A). In contrast, ER $\beta$ expression upregulated HER2 and downregulated HER3 protein levels. No further changes were seen with DPN. Treatment of T47-DER $\beta$ cells expressing ER $\beta$ or not with the ER $\alpha$-selective ligand PPT decreased HER2 protein expression but had no effect on HER3 protein expression (Additional file 2). In the control mock cell line T47-DPBI, the two doxycycline concentrations did not change HER2 and HER3 protein levels (Figure 2B), suggesting that expression of these two membrane receptors in T47-DER $\beta$ cells is regulated by $\operatorname{ER} \beta$ and not by doxycycline. In MCF-7ER $\beta$ cells, expression of HER2 protein was not clearly upregulated by ER $\beta$. However, HER3 protein expression was downregulated in MCF$7 E R \beta$ upon ER $\beta$ expression (Figure 2C), showing that ER $\beta$-induced HER3 downregulation is not seen in only one isolated cell clone and type. The ER $\beta$-induced increase in HER2 levels was also seen by performing immunocytochemistry in T47-DER $\beta$ cells (Figure 2D).

Exposure of cells to ICI or 4-OH-T induced an overall increase in expression of HER2 protein, and ER $\beta$ upregulation of HER2 was completely abolished by both ICI and 4-OH-T, as analyzed after 4 days of ER $\beta$ expression (Figure 3A). qPCR analysis showed that in cells not exposed to ICI or 4-OH-T, ER $\beta$ expression increased HER2 mRNA levels. Upon ICI or 4-OH-T exposure, HER2 mRNA levels increased, and, in this experimental setting, ER $\beta$ decreased HER2 mRNA levels. This was not clearly related to HER2 protein levels at 4 days of ER $\beta$ expression. However, following 7 days of ER $\beta$ expression, HER2 protein levels correlated with HER2 mRNA levels seen at 4 days, indicative of slow turnover of HER2 protein (Figure 3A, bottom). In a recent study, PAX2 and the ER coactivator AIB1 (SRC-3) were shown to compete for binding to $\mathrm{ER} \alpha$ and regulation of $H E R 2$ gene transcription in breast cancer cells [48]. In cells treated with estrogen or tamoxifen, PAX2 acted together with ER $\alpha$ as a transcriptional repressor where HER2 mRNA was decreased, whereas HER2 transcription increased with high levels of SRC-3. Interestingly, we show here that HER2 mRNA and protein levels were increased upon ER $\beta$ expression. E2 treatment or treatment with the ER $\alpha$-selective ligand PPT of T47-DER $\beta$ cells with no ER $\beta$ induction resulted in downregulation of HER2 protein levels (Additional files 2 and 3), indicating that under our experimental conditions, ER $\alpha$ 
A

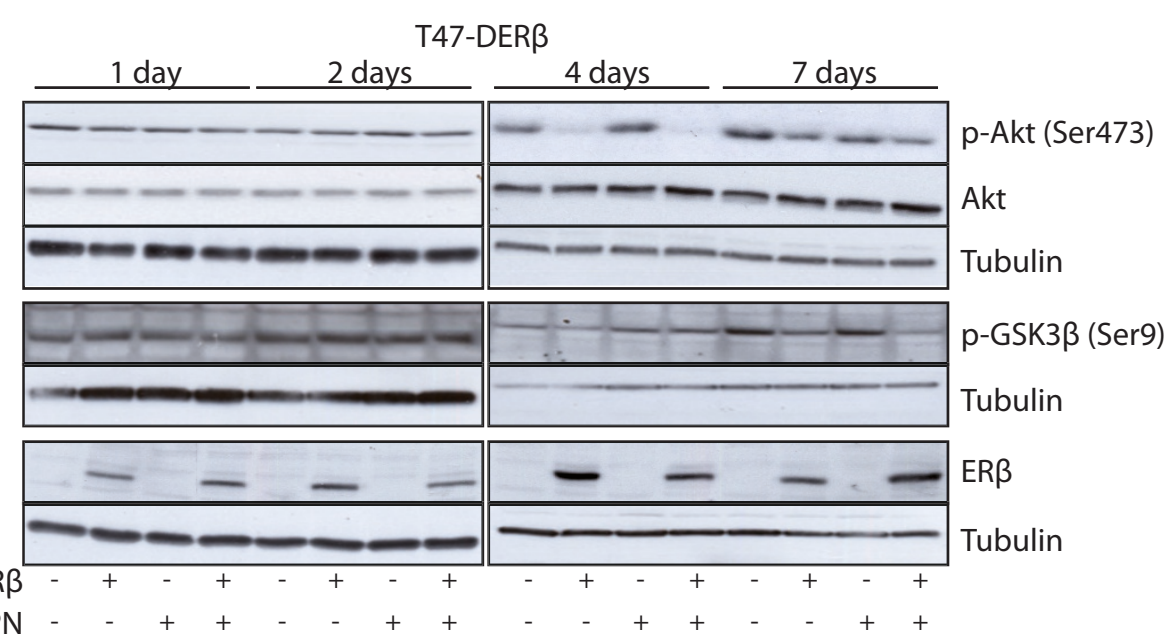

B

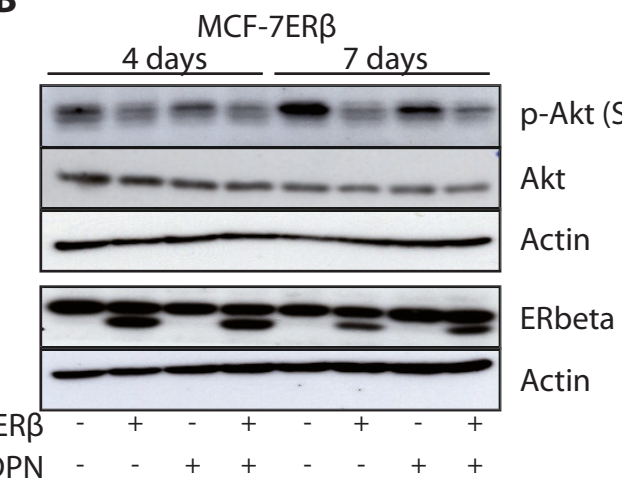

D

T47-DER $\beta$
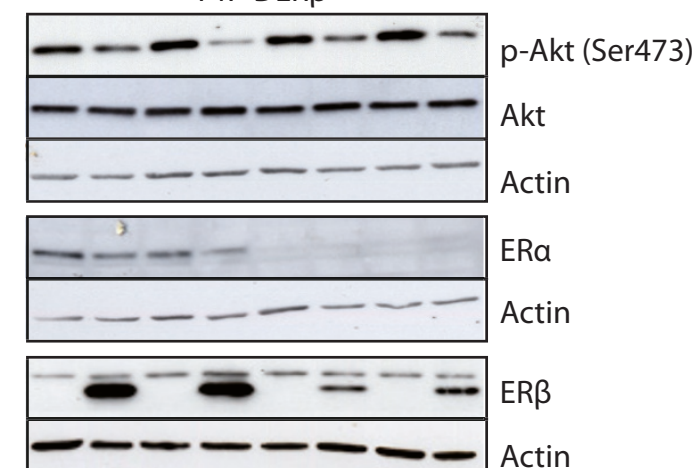

ER $\beta$

10nM DPN

100nM ICI
C

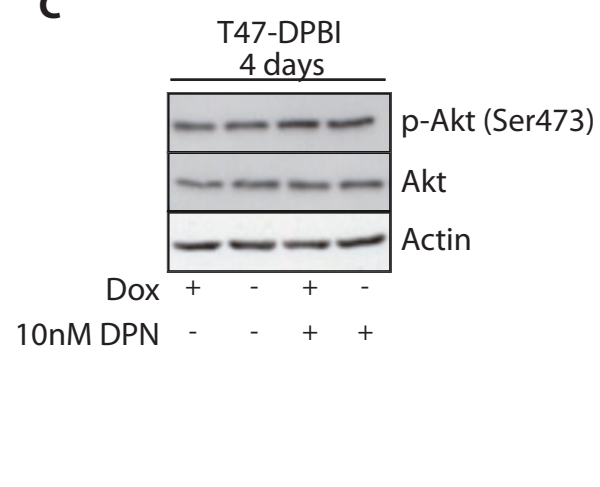

E

T47-DER $\beta$

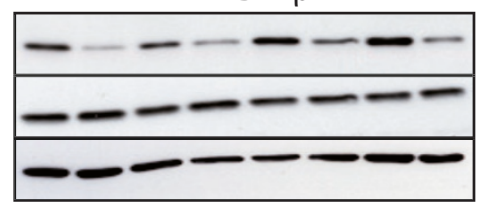

p-Akt (Ser473)

Akt

Actin

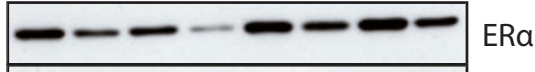

$-\infty-\infty-\infty$ Actin

Actin
Ac

Figure 1 Estrogen receptor $\boldsymbol{\beta}$ expression decreases Akt signaling in breast cancer cells. (A) T47-DER $\beta$ cells were treated for 1 day up to 7 days with $10 \mathrm{ng} / \mathrm{mL}$ (-ERß) or $0.01 \mathrm{ng} / \mathrm{mL}$ (+ERB) doxycycline in the presence or absence of $10 \mathrm{nM}$ 2,3-bis(4-hydroxy-phenyl)-propionitrile (DPN). (B) MCF-7ER $\beta$ cells were treated for 4 days or 7 days with $10 \mathrm{ng} / \mathrm{mL}$ (-ERß) or $0.01 \mathrm{ng} / \mathrm{mL}(+E R \beta)$ doxycycline in the presence or absence of 10 nM DPN. (C) T47-DPBI control cells were treated for 4 days with $10 \mathrm{ng} / \mathrm{mL}$ or $0.01 \mathrm{ng} / \mathrm{mL}$ doxycycline, in the presence or absence of $10 \mathrm{nM}$ DPN. (D and E) T47-DERß cells were treated for 4 days with $10 \mathrm{ng} / \mathrm{mL}$ (-ERß) or $0.01 \mathrm{ng} / \mathrm{mL}(+E R \beta)$ doxycycline in the presence or absence of

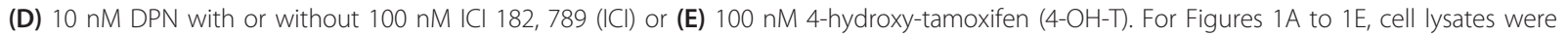
analyzed by immunoblotting. In Figure $1 A$, the estrogen receptor $\beta$ (ER $\beta$ ) antibody used was 14021 from Abcam. In Figures $1 B, 1 D$ and $1 E$, the ER $\beta$ antibody was GTX110607 from GeneTex. This antibody produced a nonspecific band above the ER $\beta$ band. 


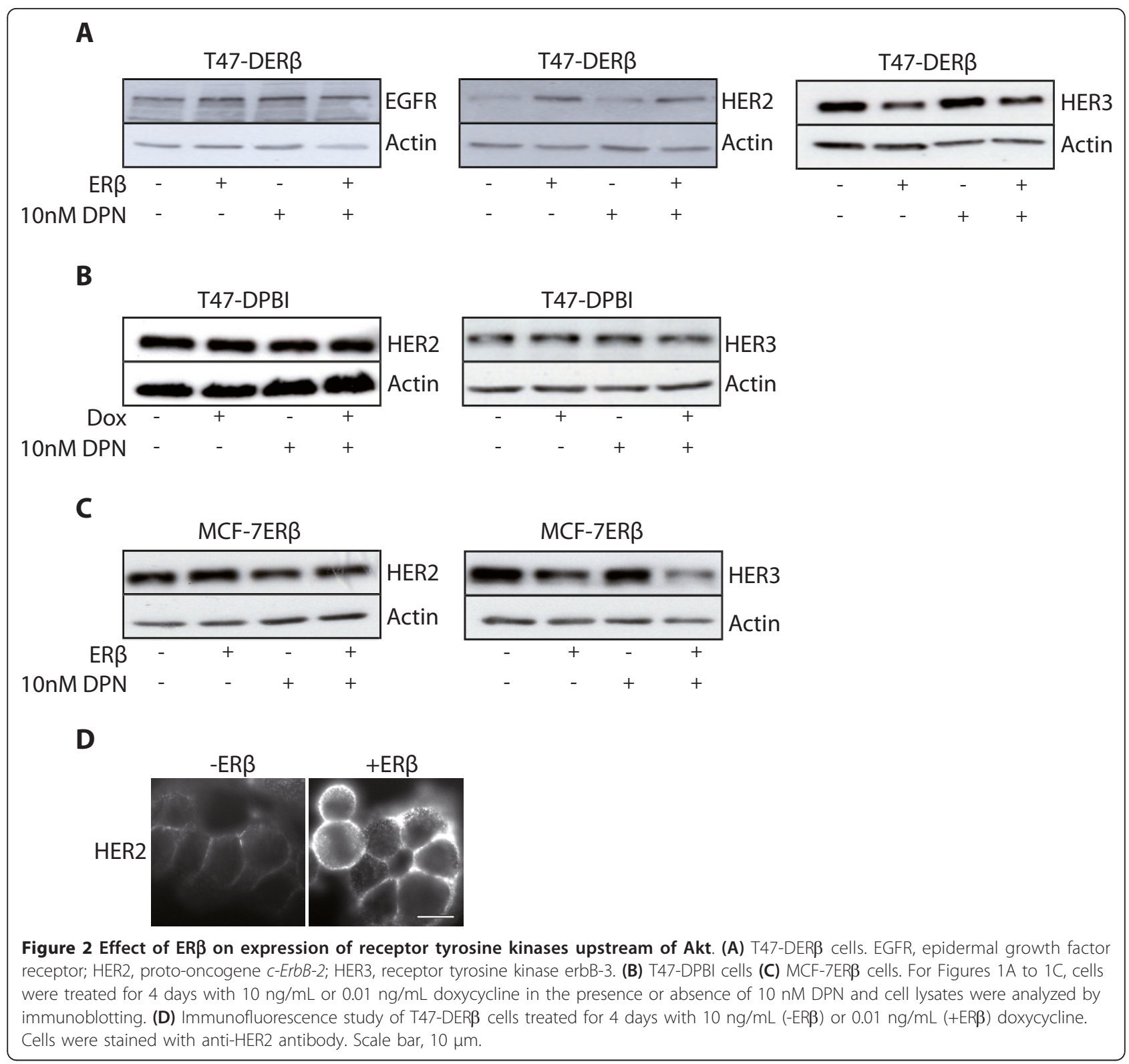

exerted a repressive effect. Thus, we hypothesize that ER $\beta$ upregulation of HER 2 could be related to reduced $\mathrm{ER} \alpha$ action by the formation of ER $\alpha / E R \beta$ heterodimers, which relieves ER $\alpha$ homodimer-mediated repression of HER2 expression, and/or by ER $\beta$ repressing the expression of $E R \alpha$, as seen in our cell models. Exposure of T47-DER $\beta$ cells to the ER antagonists ICI or 4-OH-T enhanced HER2 mRNA and protein levels, an effect that could be due to removal of the ER $\alpha$-PAX2 repressive effect on HER2 gene expression. Interestingly, when ICI or 4-OH-T was added to ER $\beta$ expressing cells, ER $\beta$ changed from being an inducer to a repressor of HER2 mRNA and protein expression. In our cell model, exposure to ICI resulted in the disappearance of ER $\alpha$ protein and a marked increase of HER2. Thus, in ICI-treated cells expressing ER $\beta$, it is likely that an ER $\beta$ homodimer is acting as a repressor of HER2 gene expression. Furthermore, 4-OH-T treatment also shifted ER $\beta$ from being an activator to being a repressor. This could perhaps be explained by 4-OH-T having an antagonistic action on ER $\alpha$ but not on ER $\beta$, a possible scenario if both receptors are activated ligand-independently by phosphorylation, where ER $\beta$ is less sensitive to antagonism from 4-OH-T [49]. It is clear that further studies with T47-DER $\beta$ cells are needed to better understand the mechanisms by which ER $\beta$ regulates HER2 expression, including determination of PAX2 and SRC-3 levels under different experimental conditions. 
A
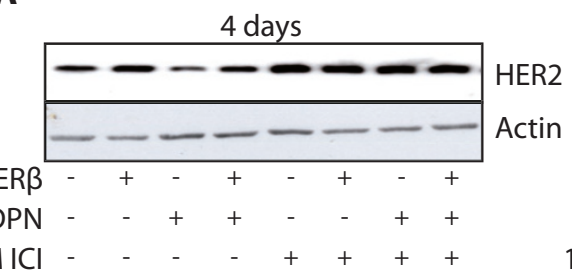

10nM DPN

100nM ICl

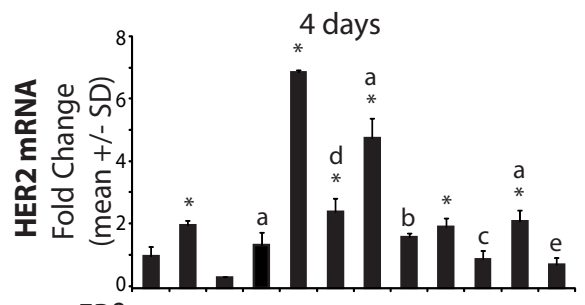

ER $\beta$

10nM DPN

$100 \mathrm{nMICl}-{ }_{-}-c_{+}++\ldots$

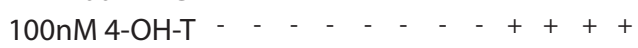
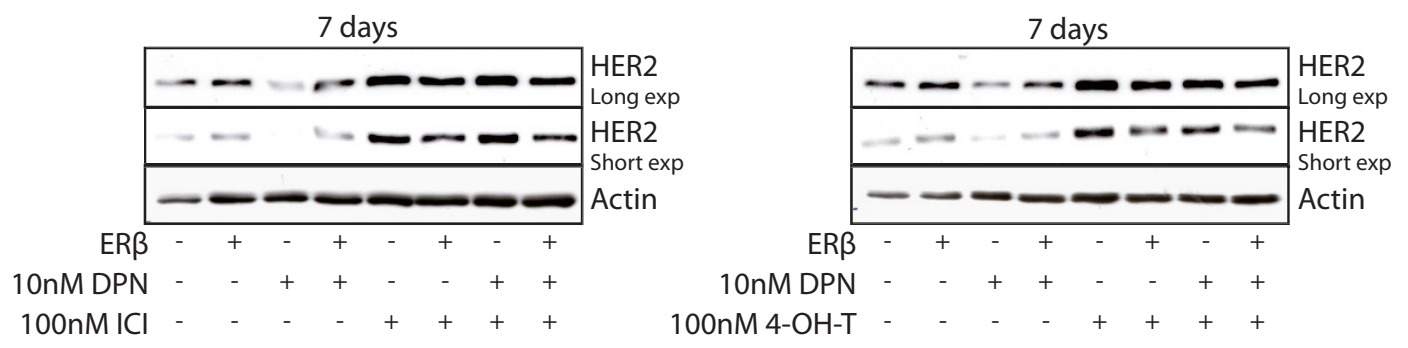

B

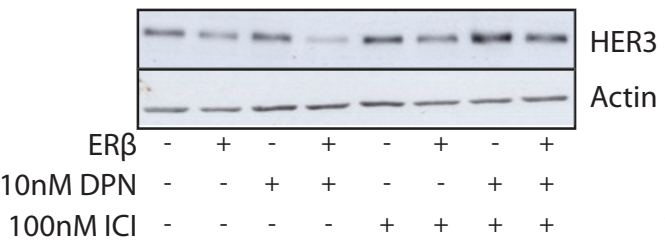

\section{HER3} Actin
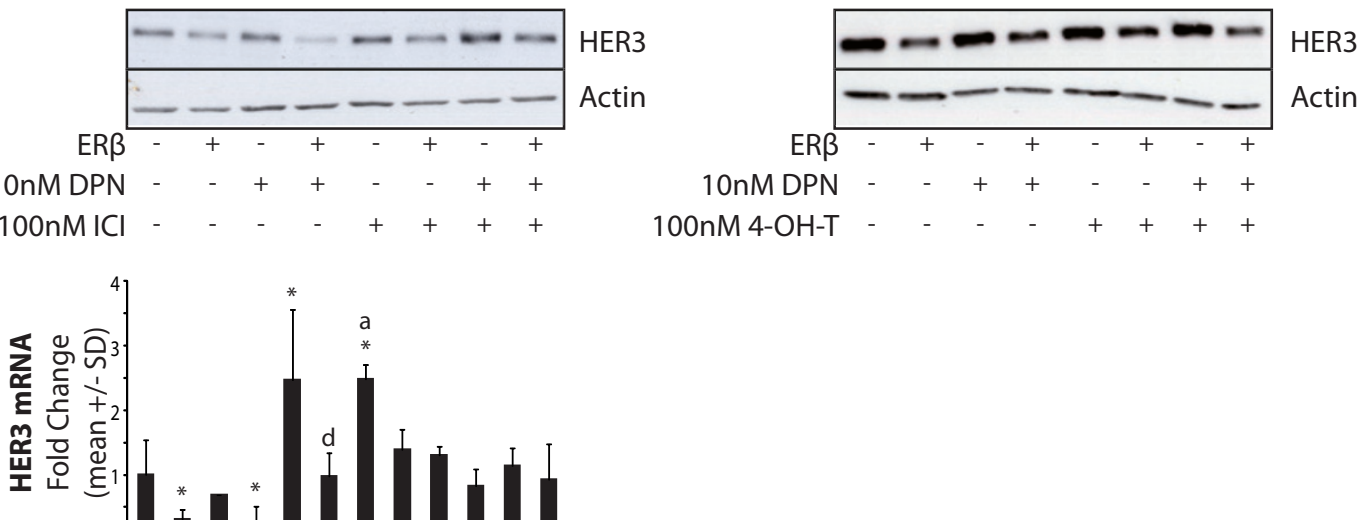

ER $\beta$

10nM DPN

$100 \mathrm{nM} \mathrm{ICl}$

100nM 4-OH-T

Figure 3 Effect of ER $\beta$ on HER2 and HER3 protein and mRNA expression. (A) T47-DER $\beta$ cells were treated for 4 or 7 days with $10 \mathrm{ng} / \mathrm{mL}$ (-ERß) or $0.01 \mathrm{ng} / \mathrm{mL}$ (+ERß) doxycycline in the presence or absence of $10 \mathrm{nM}$ DPN with or without $100 \mathrm{nM} \mathrm{ICl}$ or $100 \mathrm{nM}(4-\mathrm{OH}-\mathrm{T})$, and lysates were analyzed by immunoblotting. Also, cells were analyzed for HER2 mRNA expression by performing quantitative polymerase chain reactions (qPCRs). (B) T47-DER $\beta$ cells were treated for 4 days with $10 \mathrm{ng} / \mathrm{mL}$ (-ERß) or $0.01 \mathrm{ng} / \mathrm{mL}$ (+ERß) doxycycline in the presence or absence of $10 \mathrm{nM}$ DPN with or without $100 \mathrm{nM} \mathrm{ICl}$ or $100 \mathrm{nM} 4-\mathrm{OH}-\mathrm{T}$, and lysates were analyzed by immunoblotting. Also, cells were analyzed for HER3 mRNA expression by performing qPCR. Significant differences were analyzed using one-way analysis of variance (ANOVA) and Tukey's multiple posttest: ${ }^{*} P<0.05$ vs. $-E R \beta,{ }^{a} P<0.05$ vs. $-E R \beta+D P N,{ }^{b} p<0.05$ vs. $-E R \beta+D P N+I C I,{ }^{c} p<0.05$ vs. $-E R \beta+4-O H-T,{ }^{d} p<0.05$ vs. $-E R \beta+I C l,{ }^{e} p<0.05$ vs. $-\mathrm{ER} \beta+\mathrm{DPN}+4-\mathrm{OH}-\mathrm{T}$. 
Neither ICI nor 4-OH-T prevented ER $\beta$-induced downregulation of HER3 protein levels (Figure 3B). qRT-PCR analysis showed that ICI and 4-OH-T both increased overall HER3 mRNA levels, which could be indicative of $E R \alpha$, similarly to $E R \beta$, having a repressive effect on HER3 mRNA expression. However, the ER $\alpha$ selective ligand PPT had no effect on HER3 protein expression. Further studies are needed to explain this difference. ICI, but not 4-OH-T, clearly did not inhibit ER $\beta$-induced downregulation of HER3 mRNA. The ICIinduced increase and ER $\beta$-induced downregulation of HER3 mRNA levels in ICI-treated cells correlated well with HER3 protein levels. This was not obvious in 4$\mathrm{OH}-\mathrm{T}$ treated cells, where a difference was seen at the protein level but not at the mRNA level.

\section{ER $\beta$ downregulates heregulin-induced activation of HER2/ HER3 dimer and Akt}

Heregulin- $\beta 1$ (HRG- $\beta 1$ ), a member of the EGFR family, is a ligand for HER3. As HER3 has no intracellular tyrosine kinase domain, it partners with other members of the EGFR family to initiate intracellular signaling. The preferred dimerization partner is HER2, which has tyrosine kinase activity. In the intracellular domain of HER3, there are six tyrosines that, upon phosphorylation by HER2, will serve as docking sites for the p85 adaptor subunit of PI3K. Thus, HRG- $\beta 1$ activation of the HER2/ HER3 dimer results in strong activation of the PI3K/Akt signaling pathway.

To elucidate whether ER $\beta$ could influence HRG- $\beta 1$ activation of the HER2/HER3 and Akt pathways, T47DER $\beta$ cells were cultured for 4 days with or without ER $\beta$ expression and in the absence or presence of DPN, whereafter HRG- $\beta 1$ was added for 30 minutes. The addition of HRG- $\beta 1$ to T47-DER $\beta$ cells clearly induced phosphorylation of HER2, HER3 and Akt (Figure 4A). ER $\beta$ decreased levels of phosphorylated HER3 (Figure $4 \mathrm{~A})$. This effect probably could be explained by the ER $\beta$-induced downregulation of HER3 protein (Figures $2 \mathrm{~A}, \mathrm{D}, 3 \mathrm{~B}$ and $4 \mathrm{~A})$. Interestingly, even though $\mathrm{ER} \beta$ upregulated HER2 protein levels (Figures $2 \mathrm{~A}, \mathrm{C}, 3 \mathrm{~A}$ and $4 \mathrm{~A}$ ), ER $\beta$ decreased HRG- $\beta 1$-induced HER2 phosphorylation, also possibly due to ER $\beta$-induced decrease of the HER2 dimerization partner HER3.

Exposure of T47-DER $\beta$ cells to HRG- $\beta 1$ for 30 minutes also dramatically increased levels of pAkt (Figure $4 \mathrm{~A})$. At this time point, ER $\beta$ expression did not decrease levels of phosphorylated Akt. However, a time study of HRG- $\beta 1$-stimulated cells showed that from 2 hours onward, ER $\beta$ presence decreased levels of phosphorylated Akt (Figure 4B). One possible explanation for this could be that in the acute phase after HRG- $\beta 1$ addition, there was a massive activation of Akt due to the already mutated PIK3CA in T47-DER $\beta$ cells, an activation that ER $\beta$ could not inhibit. However, ER $\beta$ could decrease levels of phosphorylated Akt after its peak activity, when the activity was still clearly above that in unstimulated cells (Figure 4A).

Exposure of cells to DPN, E2 or WAY (another ER $\beta$ selective agonist) did not influence levels of HRG- $\beta 1$ induced phosphorylated HER2, HER3 and Akt (Figure 4A andAdditional file 3). To further investigate the Akt pathway in the context of endocrine sensitivity and ER $\beta$ expression, in addition to HRG- $\beta 1$ treatment, cells were further treated with ICI or 4-OH-T (Figure 4A). ICI and 4- $\mathrm{OH}-\mathrm{T}$ exposure both increased levels of phosphorylated HER2 and HER3 in the absence or presence of ER $\beta$. An effect that may be related to increased total HER2 levels in cells treated with ICI or 4-OH-T (Figures 3A and 4A). However, levels of phosphorylated HER2 and pHER3 were clearly lower when ER $\beta$ was present.

\section{PTEN levels increase following ER $\beta$ expression}

PTEN mediates its main tumor-suppressive function through dephosphorylation of PIP3. Interestingly, in a recent report [50], it was shown that in mice with a subtle reduction of PTEN expression (80\% of the normal level), different types of tumors developed with mammary carcinomas occurring at highest penetrance. Also, reduced levels or loss of PTEN has been implicated in the development of endocrine resistance in breast cancer. Since PTEN is an important regulator of Akt signaling, we found it important to investigate the effect of ER $\beta$ on PTEN expression. ER $\beta$ expression upregulated PTEN levels in both T47-DER $\beta$ and MCF7ER $\beta$ cells (Figure 5A). DPN, E2 or WAY addition did not further upregulate PTEN levels (Figure 5A and Additional file 4). No significant changes were seen in the control cell line (T47-DPBI) under the same conditions (Figure 5A). Thus, the ER $\beta$ effect on PTEN levels was seen not only in one breast cancer cell type and was not due to doxycycline. The T47-DER $\beta$ cells expressing ER $\beta$ or not were also analyzed using PTEN immunofluorescence. As shown in Figure 5B, PTEN protein levels were clearly upregulated in ER $\beta$-expressing cells. Exposure of T47-DER $\beta$ cells to ICI or 4-OH-T did not decrease or inhibit the ER $\beta$ effect on PTEN protein levels (Figure 5C and Additional file 5). The effect of ER $\beta$ expression on PTEN mRNA levels was also investigated. However, no conclusive data could be obtained from these experiments (data not shown). One explanation for the observed effects of ER $\beta$ on PTEN protein levels could be that ER $\beta$ regulates expression of other proteins that in turn regulate PTEN. Further studies are needed to clarify this hypothesis. 


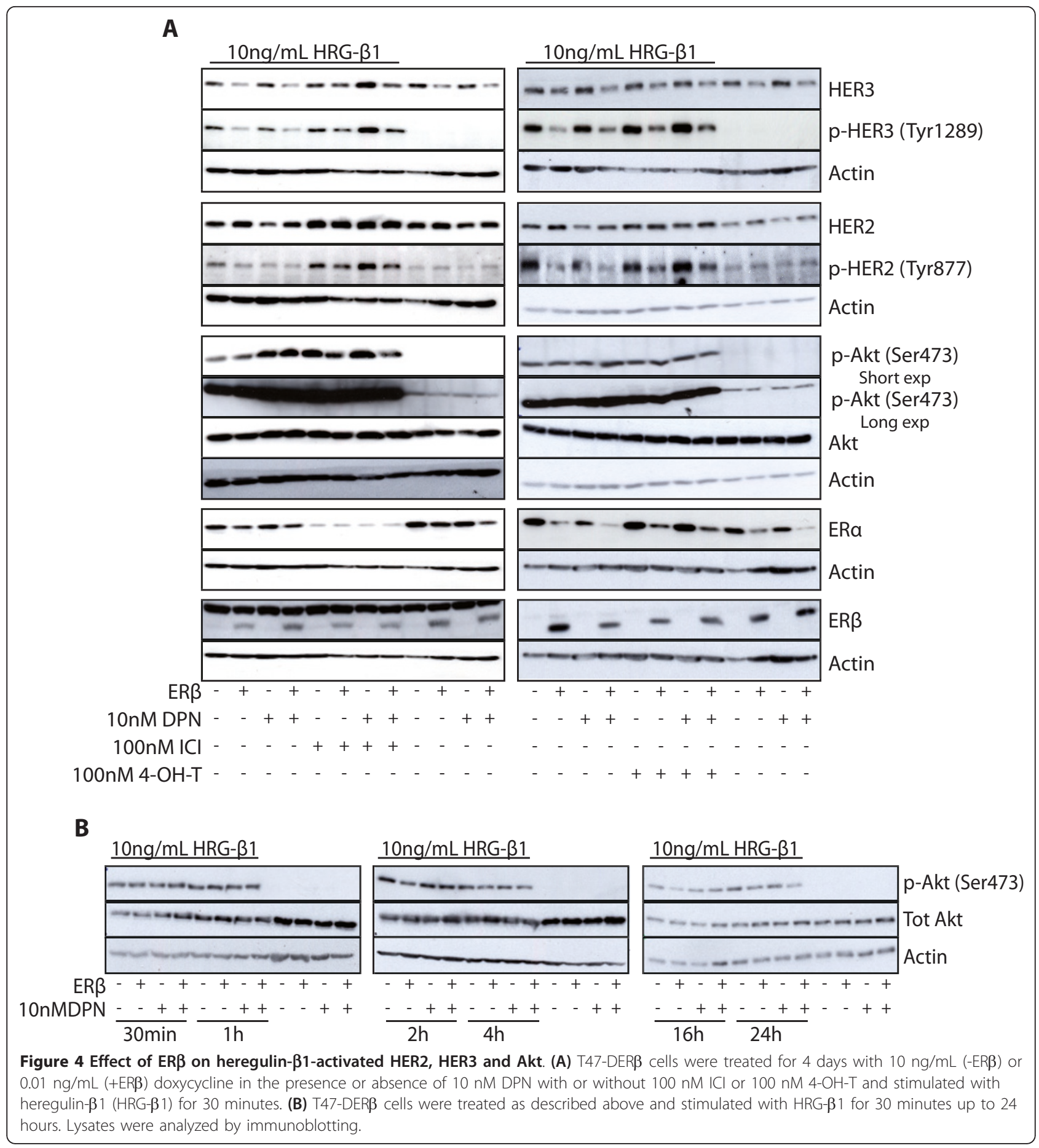

\section{Expression of ER $\beta$ sensitizes breast cancer cells to} tamoxifen

PTEN downregulation as well as increased HER2/HER3 and Akt signaling have been associated with endocrine resistance in breast tumors. With our above-described results in mind, we found it imperative to investigate whether expression of ER $\beta$ would increase the sensitivity to tamoxifen in T47-DER $\beta$ and MCF-7ER $\beta$ breast cancer cells. Experiments were performed in cells where ER $\beta$ was expressed for 4 days in the absence or presence of the agonists E2 and WAY, whereafter 1,000 nM tamoxifen was added for either 5 days (T47-DER $\beta$ ) or 7 days (MCF-7ER $\beta$ ). The selective agonist DPN was not used in these experiments because of our previous 


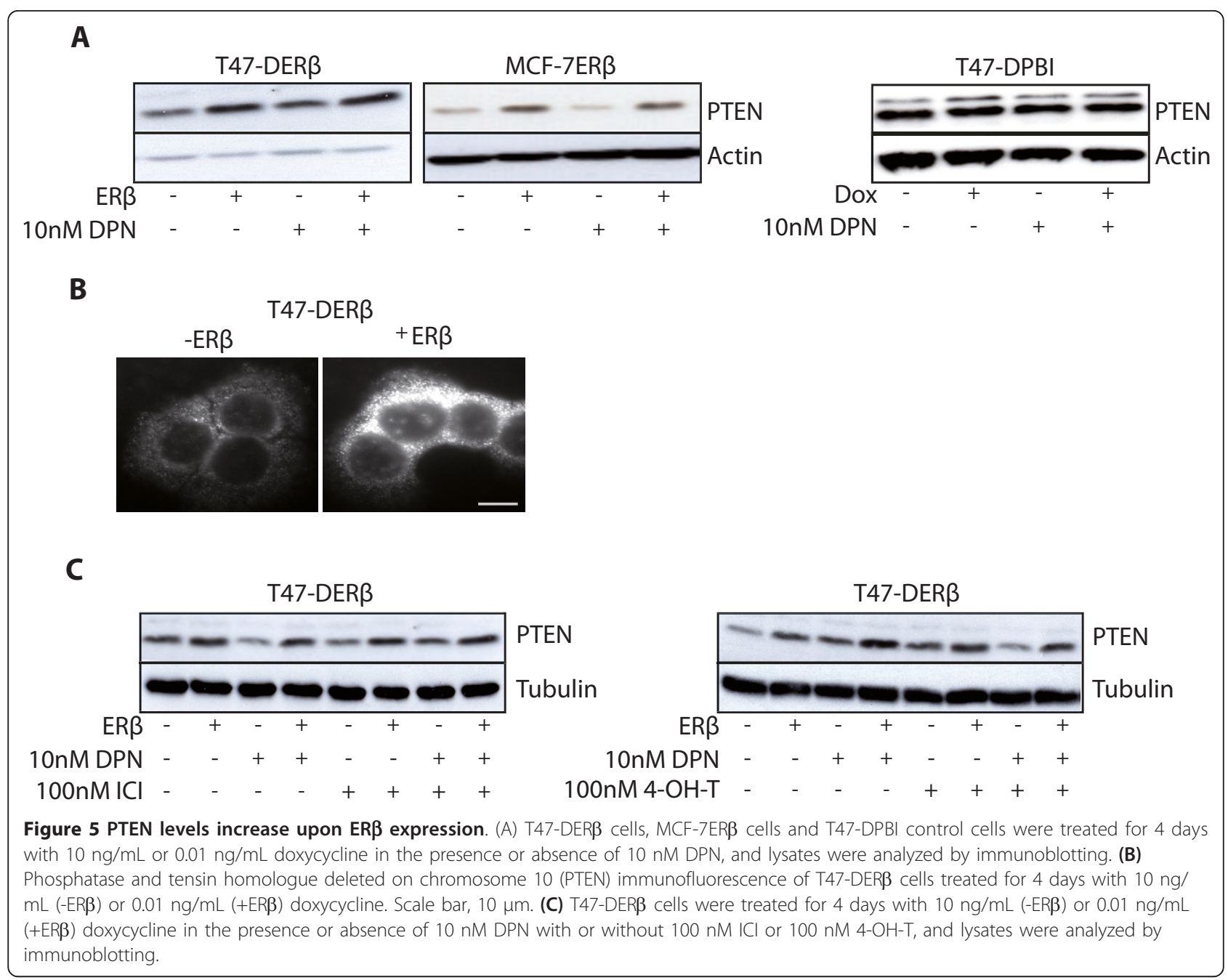

findings that, besides inhibiting proliferation, DPN also seems to affect this kind of viability assay, depending on metabolism [51]. Instead, the selective ER $\beta$ ligand WAY was used, which did not influence the assay. In both cell lines, and in the absence of ER $\beta, 4-\mathrm{OH}-\mathrm{T}$ decreased growth (Figure 6). In MCF-7ER $\beta$ cells, we observed a more marked effect, which could be due to less active Akt signaling (Additional file 1). In MCF-7ER $\beta$ cells, but not in T47-DER $\beta$ cells, E2 also slightly counteracted the effect of 4-OH-T. Expression of ER $\beta$ alone clearly reduced growth in both cell lines. This was further significantly enhanced with exposure to WAY in ER $\beta$ expressing T47-DER $\beta$ cells. In MCF-7ER $\beta$ cells, a slight enhancement of growth reduction was also seen with WAY treatment, but it did not reach significance. Expression of ER $\beta$, together with exposure to 4-OH-T, significantly further decreased cell growth as compared to growth seen in only ER $\beta$-expressing cells. Similar results were seen in both cell lines with $500 \mathrm{nM}$ tamoxifen (results not shown). In summary, these results show that ER $\beta$ expression render ER $\alpha$-expressing breast cancer cells more sensitive to tamoxifen treatment.

In several experiments, the addition of agonist or antagonist did not increase or decrease the effect of ER $\beta$ expression on its own. This could indicate that in these breast tumor cells, ER $\beta$ is activated in a ligand-independent manner; for example, it is phosphorylated in the AF-1 domain and then is also less inhibited by antagonists that have a focus on ligand-binding and the AF-2 domain [49]. Further studies are needed to clarify this hypothesis with mapping of phosphorylated sites of ER $\beta$ in these cells. Interestingly, a recent report [52] shows that ER $\beta$ phosphorylated at serine 105 is associated with a good prognosis in breast cancer. A future challenge is to develop ligands that, in this setting, that is, ER $\beta$ expressing breast cancers with increased kinase activity, could activate or increase the inhibitory effect of ER $\beta$ on Akt signaling. 


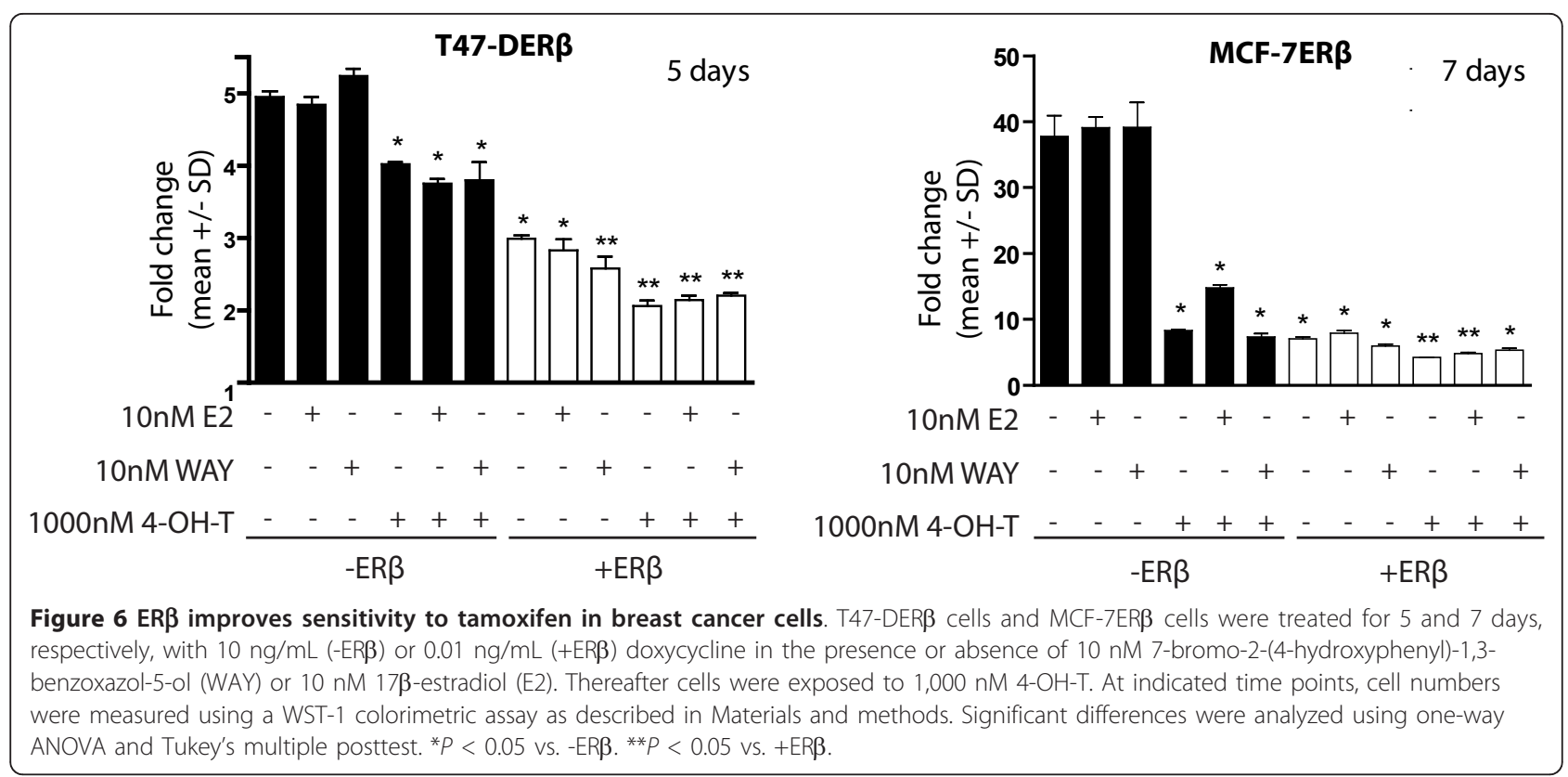

\section{Conclusions}

Our results suggest a link between expression of ER $\beta$ and endocrine sensitivity by increasing PTEN levels and decreasing HER2/HER3 signaling, thereby reducing Akt signaling with subsequent effects on proliferation, survival and tamoxifen sensitivity of breast cancer cells. This study supports initiatives to further investigate whether ER $\beta$ presence in breast cancer samples is an indicator for endocrine response. Current therapies in ER $\alpha$-positive breast cancers aim to impair ER $\alpha$ activity with antagonists or by removal of endogenous estrogens with aromatase inhibitors. Data from this study could be taken as indicative for using ER $\beta$ as a target in selected groups of breast cancer.

\section{Additional material}

Additional file 1: Western blot analysis of Akt signaling in T47D and MCF-7 cells. T47-DER $\beta$ and MCF-7ER $\beta$ cells were treated for 4 days with $10 \mathrm{ng} / \mathrm{mL}$ (-ERß) or $0.01 \mathrm{ng} / \mathrm{mL}$ (+ERß) doxycycline in the presence or absence of $10 \mathrm{nM}$ 2,3-bis(4-hydroxy-phenyl)-propionitrile (DPN). Lysates were analyzed by immunoblotting. ER $\beta$, estrogen receptor $\beta$.

Additional file 2: Effects of the ER $\alpha$-selective ligand PPT on expression of HER2 and HER3. T47-DER $\beta$ cells were treated for 4 days with $10 \mathrm{ng} / \mathrm{mL}(-E R \beta)$ or $0.01 \mathrm{ng} / \mathrm{mL}$ (+ERß) doxycycline, in the presence or absence of 10 nM 4,49,400-(4-propyl-[1 H]-pyrazole-1,3,5-triyl)trisphenol (PPT). Lysates were analyzed by immunoblotting.

Additional file 3: Influence of different ER ligands on ER $\beta$ effects on HRG- $\beta$ 1-stimulated signaling. T47-DER $\beta$ cells were treated for 4 days with $10 \mathrm{ng} / \mathrm{mL}(-E R \beta)$ or $0.01 \mathrm{ng} / \mathrm{mL}$ (+ERß) doxycycline in the presence or absence of 10 nM DPN, 10 nM 7-bromo-2-(4-hydroxyphenyl)-1,3benzoxazol-5-ol (WAY) or $10 \mathrm{nM} 17 \beta$-estradiol (E2) and thereafter were stimulated for 30 minutes with $10 \mathrm{ng} / \mathrm{mL}$ heregulin $\beta 1$ (HRG- $\beta 1$ ). Lysates were analyzed by immunoblotting.

Additional file 4: ER $\beta$ effects on PTEN protein expression using different ER selective ligands. T47-DER $\beta$ cells were treated for 4 days with $10 \mathrm{ng} / \mathrm{mL}$ (-ERß) or $0.01 \mathrm{ng} / \mathrm{mL}$ (+ERß) doxycycline in the presence or absence of $10 \mathrm{nM}$ DPN, $10 \mathrm{nM}$ WAY or $10 \mathrm{nM}$ E2. Lysates were analyzed by immunoblotting. PTEN, phosphatase and tensin homologue deleted on chromosome 10.

Additional file 5: Influence of ER antagonists on ER $\beta$ effects on PTEN protein expression. T47-DER $\beta$ cells were treated for 4 days with $10 \mathrm{ng} / \mathrm{mL}$ (-ERß) or $0.01 \mathrm{ng} / \mathrm{mL}$ (+ERß) doxycycline in the presence or absence of 10 nM DPN, 100 nM 4-OH-T or 100 nM ICI 182, 789 (ICI). Lysates were analyzed by immunoblotting. Densitometric scanning of three immunoblots is shown.

\section{Abbreviations}

DPN: 2,3-bis(4-hydroxy-phenyl)-propionitrile; EGFR: epidermal growth factor receptor; ER: estrogen receptor; E2: 17ß-estradiol; HER2 proto-oncogene cErbB-2; HER3: receptor tyrosine kinase erbB-3; HRG- $\beta 1$ : heregulin- $\beta 1$; ICl: ICI 182: 789; 4-OH-T: 4-hydroxy-tamoxifen; PCR: polymerase chain reaction; PI3K: phosphatidylinositol 3-kinase; PIP3: phosphatidylinositol $(3,4,5)$-triphosphate; PPT: 4,4',4"-(4-propyl-[1 H]-pyrazole-1,3,5-triyl)trisphenol; PTEN: phosphatase and tensin homologue deleted on chromosome 10; qPCR: quantitative realtime polymerase chain reaction; RTK: receptor tyrosine kinase; WAY: 7bromo-2-(4-hydroxyphenyl)-1,3-benzoxazol-5-ol.

\section{Acknowledgements}

We thank Dr Anders Ström for providing us with T47-D-inducible and MCF-7 ERß-inducible cells. This study was supported by grants from the Swedish Cancer Fund and from the Welch Foundation. Luisa Helguero is supported by the Portuguese Science and Technology Foundation projects Ciencia 2008 and PTDC/SAU-ONC/112671/2009. The funding agencies had no role in the study design; in the collection, analysis and interpretation of data; in the writing of the manuscript; or in the decision to submit the manuscript for publication.

\section{Author details}

'Department of Biosciences and Nutrition, Novum, Karolinska Institutet, Blickagången 6, S-141 83 Huddinge, Sweden. ${ }^{2}$ Department of Organic Chemistry and Natural Products, University of Aveiro, Avenida da Universidade, 3810-193 Aveiro, Portugal. ${ }^{3}$ Center for Nuclear Receptors and Cell Signaling, Department of Biology and Biochemistry, 3605 Cullen Boulevard, SERC Bldg 545, University of Houston, Houston, TX 77204-5056, USA. 


\section{Authors' contributions}

$\mathrm{KL}$ participated in the study design and coordination; carried out the cell cultures, Western blot analysis and RT-PCR analyses; and drafted the manuscript. LH conceived of the study, participated in its design and helped to draft the manuscript. YO optimized, performed, analyzed and interpreted data from immunostaining and helped to draft the manuscript. JÅG participated in general discussions of the project, helped to draft the manuscript and revised it critically for important intellectual content. LAH conceived of the study, participated in the design of the study, performed some Western blot analyses and helped to draft the manuscript. All authors read and approved the final manuscript.

\section{Competing interests}

$J \AA ̊ G$ received a consultancy honorarium and has an ownership interest in KaroBio $\mathrm{AB}$ and is a consultant for Bionovo. The other authors declare that they have no competing interests.

Received: 9 November 2010 Revised: 24 March 2011

Accepted: 14 April 2011 Published: 14 April 2011

\section{References}

1. Hiscox S, Davies EL, Barrett-Lee P: Aromatase inhibitors in breast cancer. Maturitas 2009, 63:275-279.

2. Jordan VC, Dowse L: Tamoxifen as an anti-tumour agent: effect on oestrogen binding. J Endocrinol 1976, 68:297-303.

3. Nilsson M, Dahlman-Wright K, Gustafsson JA: Nuclear receptors in disease: the oestrogen receptors. Essays Biochem 2004, 40:157-167.

4. Strom A, Hartman J, Foster JS, Kietz S, Wimalasena J, Gustafsson JA: Estrogen receptor $\beta$ inhibits $17 \beta$-estradiol-stimulated proliferation of the breast cancer cell line T47D. Proc Natl Acad Sci USA 2004, 101:1566-1571.

5. Lazennec G, Bresson D, Lucas A, Chauveau C, Vignon F: ERß inhibits proliferation and invasion of breast cancer cells. Endocrinology 2001, 142:4120-4130.

6. Lindberg $K$, Ström A, Lock JG, Gustafsson JA, Haldosén LA, Helguero LA: Expression of estrogen receptor $\beta$ increases integrin $\alpha 1$ and integrin $\beta$ levels and enhances adhesion of breast cancer cells. J Cell Physiol 2010, 222:156-167.

7. Paruthiyil S, Parmar H, Kerekatte V, Cunha GR, Firestone GL, Leitman DC: Estrogen receptor $\beta$ inhibits human breast cancer cell proliferation and tumor formation by causing a G2 cell cycle arrest. Cancer Res 2004, 64:423-428.

8. Chang EC, Frasor J, Komm B, Katzenellenbogen BS: Impact of estrogen receptor $\beta$ on gene networks regulated by estrogen receptor $a$ in breast cancer cells. Endocrinology 2006, 147:4831-4842.

9. Rayner K, Chen YX, Hibbert B, White D, Miller H, Postel EH, O'Brien ER: Discovery of $\mathrm{NM} 23-\mathrm{H} 2$ as an estrogen receptor $\beta$-associated protein: role in estrogen-induced gene transcription and cell migration. J Steroid Biochem Mol Biol 2008, 108:72-81.

10. Hartman J, Lindberg K, Morani A, Inzunza J, Ström A, Gustafsson JA: Estrogen receptor $\beta$ inhibits angiogenesis and growth of T47D breast cancer xenografts. Cancer Res 2006, 66:11207-11213.

11. Osborne CK: Steroid hormone receptors in breast cancer management. Breast Cancer Res Treat 1998, 51:227-238.

12. Fox EM, Davis RJ, Shupnik MA: ERß in breast cancer: onlooker, passive player, or active protector? Steroids 2008, 73:1039-1051.

13. Chen JQ, Russo J: ERa-negative and triple negative breast cancer: molecular features and potential therapeutic approaches. Biochim Biophys Acta 2009, 1796:162-175.

14. Nicholson $S$, Halcrow $P$, Sainsbury JR, Angus $B$, Chambers P, Farndon JR, Harris AL: Epidermal growth factor receptor (EGFr) status associated with failure of primary endocrine therapy in elderly postmenopausal patients with breast cancer. Br J Cancer 1988, 58:810-814.

15. Arpino G, Green SJ, Allred DC, Lew D, Martino S, Osborne CK, Elledge RM: HER-2 amplification, HER-1 expression, and tamoxifen response in estrogen receptor-positive metastatic breast cancer: a Southwest Oncology Group study. Clin Cancer Res 2004, 10:5670-5676.

16. Berry DA, Muss HB, Thor AD, Dressler L, Liu ET, Broadwater G, Budman DR, Henderson IC, Barcos M, Hayes D, Norton L: HER-2/neu and p53 expression versus tamoxifen resistance in estrogen receptor-positive, node-positive breast cancer. J Clin Oncol 2000, 18:3471-3479.
17. De Laurentiis M, Arpino G, Massarelli E, Ruggiero A, Carlomagno C, Ciardiello F, Tortora G, D'Agostino D, Caputo F, Cancello G, Montagna E, Malorni L, Zinno L, Lauria R, Bianco AR, De Placido S: A meta-analysis on the interaction between HER-2 expression and response to endocrine treatment in advanced breast cancer. Clin Cancer Res 2005, 11:4741-4748.

18. Wiseman SM, Makretsov N, Nielsen TO, Gilks B, Yorida E, Cheang M, Turbin D, Gelmon K, Huntsman DG: Coexpression of the type 1 growth factor receptor family members HER-1, HER-2, and HER-3 has a synergistic negative prognostic effect on breast carcinoma survival. Cancer 2005, 103:1770-1777.

19. Tovey S, Dunne B, Witton CJ, Forsyth A, Cooke TG, Bartlett JM: Can molecular markers predict when to implement treatment with aromatase inhibitors in invasive breast cancer? Clin Cancer Res 2005, 11:4835-4842.

20. Newby JC, Johnston SR, Smith IE, Dowsett M: Expression of epidermal growth factor receptor and c-erbB2 during the development of tamoxifen resistance in human breast cancer. Clin Cancer Res 1997, 3:1643-1651.

21. Shou J, Massarweh S, Osborne CK, Wakeling AE, Ali S, Weiss H, Schiff R: Mechanisms of tamoxifen resistance: increased estrogen receptor-HER2/ neu cross-talk in ER/HER2-positive breast cancer. J Natl Cancer Inst 2004, 96:926-935.

22. Sergina NV, Rausch M, Wang D, Blair J, Hann B, Shokat KM, Moasser MM: Escape from HER-family tyrosine kinase inhibitor therapy by the kinaseinactive HER3. Nature 2007, 445:437-441.

23. Siegel PM, Ryan ED, Cardiff RD, Muller WJ: Elevated expression of activated forms of Neu/ErbB-2 and ErbB-3 are involved in the induction of mammary tumors in transgenic mice: implications for human breast cancer. EMBO J 1999, 18:2149-2164.

24. Piechocki MP, Yoo GH, Dibbley SK, Lonardo F: Breast cancer expressing the activated HER2/neu is sensitive to gefitinib in vitro and in vivo and acquires resistance through a novel point mutation in the HER2/neu. Cancer Res 2007, 67:6825-6843.

25. Liu B, Ordonez-Ercan D, Fan Z, Edgerton SM, Yang X, Thor AD: Downregulation of erbB3 abrogates erbB2-mediated tamoxifen resistance in breast cancer cells. Int J Cancer 2007, 120:1874-1882

26. Hennessy BT, Smith DL, Ram PT, Lu Y, Mills GB: Exploiting the PI3K/AKT pathway for cancer drug discovery. Nat Rev Drug Discov 2005, 4:988-1004.

27. Pérez-Tenorio G, Stål O, Southeast Sweden Breast Cancer Group: Activation of AKT/PKB in breast cancer predicts a worse outcome among endocrine treated patients. Br J Cancer 2002, 86:540-545.

28. Stål O, Pérez-Tenorio G, Akerberg L, Olsson B, Nordenskjöld B, Skoog L, Rutqvist LE: Akt kinases in breast cancer and the results of adjuvant therapy. Breast Cancer Res 2003, 5:R37-44.

29. Sun M, Wang G, Paciga JE, Feldman RI, Yuan ZQ, Ma XL, Shelley SA, Jove R, Tsichlis PN, Nicosia SV, Cheng JQ: AKT1/PKBa kinase is frequently elevated in human cancers and its constitutive activation is required for oncogenic transformation in NIH3T3 cells. Am J Pathol 2001, 159:431-437.

30. Levine DA, Bogomolniy F, Yee CJ, Lash A, Barakat RR, Borgen PI, Boyd J: Frequent mutation of the PIK3CA gene in ovarian and breast cancers. Clin Cancer Res 2005, 11:2875-2878.

31. Saal LH, Holm K, Maurer M, Memeo L, Su T, Wang X, Yu JS, Malmström PO, Mansukhani M, Enoksson J, Hibshoosh H, Borg A, Parsons R: PIK3CA mutations correlate with hormone receptors, node metastasis, and ERBB2, and are mutually exclusive with PTEN loss in human breast carcinoma. Cancer Res 2005, 65:2554-2559.

32. Campbell IG, Russell SE, Choong DY, Montgomery KG, Ciavarella ML, Hooi CS, Cristiano BE, Pearson RB, Phillips WA: Mutation of the PIK3CA gene in ovarian and breast cancer. Cancer Res 2004, 64:7678-7681.

33. Jackson JG, Kreisberg Jl, Koterba AP, Yee D, Brattain MG: Phosphorylation and nuclear exclusion of the forkhead transcription factor FKHR after epidermal growth factor treatment in human breast cancer cells. Oncogene 2000, 19:4574-4581.

34. Liu W, Li J, Roth RA: Heregulin regulation of Akt/protein kinase B in breast cancer cells. Biochem Biophys Res Commun 1999, 261:897-903.

35. Neve RM, Sutterluty H, Pullen N, Lane HA, Daly JM, Krek W, Hynes NE: Effects of oncogenic ErbB2 on G1 cell cycle regulators in breast tumour cells. Oncogene 2000, 19:1647-1656.

36. Zhou BP, Liao Y, Xia W, Spohn B, Lee MH, Hung MC: Cytoplasmic localization of $\mathrm{p} 21^{\text {Cip } 1 / \text { WAF1 }}$ by Akt-induced phosphorylation in HER-2/ neu-overexpressing cells. Nat Cell Biol 2001, 3:245-252. 
37. Zhou BP, Hu MC, Miller SA, Yu Z, Xia W, Lin SY, Hung MC: HER-2/neu blocks tumor necrosis factor-induced apoptosis via the Akt/NF-KB pathway. J Biol Chem 2000, 275:8027-8031.

38. Bacus SS, Altomare DA, Lyass L, Chin DM, Farrell MP, Gurova K, Gudkov A, Testa JR: AKT2 is frequently upregulated in HER-2/neu-positive breast cancers and may contribute to tumor aggressiveness by enhancing cell survival. Oncogene 2002, 21:3532-3540.

39. Kirkegaard T, Witton CJ, McGlynn LM, Tovey SM, Dunne B, Lyon A, Bartlett JM: AKT activation predicts outcome in breast cancer patients treated with tamoxifen. J Pathol 2005, 207:139-146.

40. Nicholson KM, Streuli CH, Anderson NG: Autocrine signalling through erbB receptors promotes constitutive activation of protein kinase $B / A k t$ in breast cancer cell lines. Breast Cancer Res Treat 2003, 81:117-128.

41. Saal LH, Johansson P, Holm K, Gruvberger-Saal SK, She QB, Maurer M, Koujak S, Ferrando AA, Malmström P, Memeo L, Isola J, Bendahl PO, Rosen N, Hibshoosh $H$, Ringnér $M$, Borg A, Parsons R: Poor prognosis in carcinoma is associated with a gene expression signature of aberrant PTEN tumor suppressor pathway activity. Proc Natl Acad Sci USA 2007, 104:7564-7569.

42. Depowski PL, Rosenthal SI, Ross JS: Loss of expression of the PTEN gene protein product is associated with poor outcome in breast cancer. Mod Pathol 2001, 14:672-676.

43. Leslie NR, Downes CP: PTEN function: how normal cells control it and tumour cells lose it. Biochem J 2004, 382:1-11.

44. Perren A, Weng LP, Boag AH, Ziebold U, Thakore K, Dahia PL, Komminoth P, Lees JA, Mulligan LM, Mutter GL, Eng C: Immunohistochemical evidence of loss of PTEN expression in primary ductal adenocarcinomas of the breast. Am J Pathol 1999, 155:1253-1260.

45. Cantley LC, Neel BG: New insights into tumor suppression: PTEN suppresses tumor formation by restraining the phosphoinositide 3kinase/AKT pathway. Proc Natl Acad Sci USA 1999, 96:4240-4245.

46. Muller P, Kietz S, Gustafsson JA, Strom A: The anti-estrogenic effect of alltrans-retinoic acid on the breast cancer cell line MCF-7 is dependent on HES-1 expression. J Biol Chem 2002, 277:28376-28379.

47. Hollestelle A, Elstrodt F, Nagel JH, Kallemeijn WW, Schutte M: Phosphatidylinositol-3-OH kinase or RAS pathway mutations in human breast cancer cell lines. Mol Cancer Res 2007, 5:195-201.

48. Hurtado A, Holmes KA, Geistlinger TR, Hutcheson IR, Nicholson RI, Brown M, Jiang J, Howat WJ, Ali S, Carroll JS: Regulation of ERBB2 by oestrogen receptor-PAX2 determines response to tamoxifen. Nature 2008, 456:663-666.

49. Sanchez M, Picard N, Sauvé K, Tremblay A: Challenging estrogen receptor $\beta$ with phosphorylation. Trends Endocrinol Metab 2010, 21:104-110.

50. Alimonti A, Carracedo A, Clohessy JG, Trotman LC, Nardella C, Egia A, Salmena L, Sampieri K, Haveman WJ, Brogi E, Richardson AL, Zhang J, Pandolfi PP: Subtle variations in Pten dose determine cancer susceptibility. Nat Genet 2010, 42:454-458.

51. Helguero LA, Faulds MH, Gustafsson JA, Haldosén LA: Estrogen receptors a $(E R a)$ and $\beta$ (ER $\beta$ ) differentially regulate proliferation and apoptosis of the normal murine mammary epithelial cell line HC11. Oncogene 2005, 24:6605-6616.

52. Hamilton-Burke W, Coleman L, Cummings M, Green CA, Holliday DL, Horgan K, Maraqa L, Peter MB, Pollock S, Shaaban AM, Smith L, Speirs V: Phosphorylation of estrogen receptor $\beta$ at serine 105 is associated with good prognosis in breast cancer. Am J Pathol 2010, 177:1079-1086.

doi:10.1186/bcr2865

Cite this article as: Lindberg et al:: Estrogen receptor $\beta$ represses Akt signaling in breast cancer cells via downregulation of HER2/HER3 and upregulation of PTEN: implications for tamoxifen sensitivity. Breast Cancer Research 2011 13:R43.

\section{Submit your next manuscript to BioMed Central and take full advantage of:}

- Convenient online submission

- Thorough peer review

- No space constraints or color figure charges

- Immediate publication on acceptance

- Inclusion in PubMed, CAS, Scopus and Google Scholar

- Research which is freely available for redistribution

Submit your manuscript at www.biomedcentral.com/submit
Biomed Central 